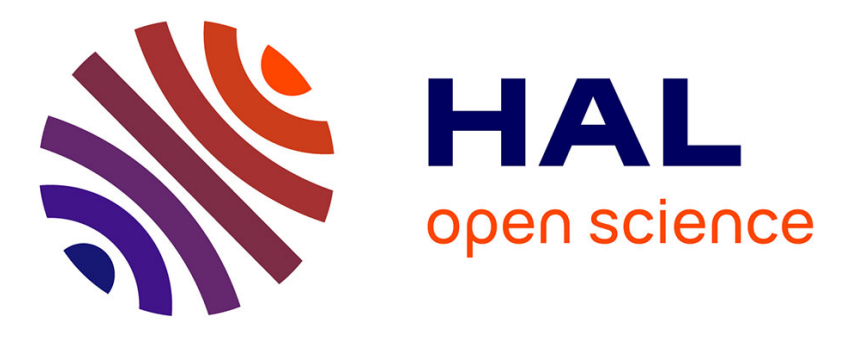

\title{
Monitoring landfill cover by electrical resistivity tomography on an experimental site
} Fanny Genelle, Colette Sirieix, Joëlle Riss, Véronique Naudet

\section{To cite this version:}

Fanny Genelle, Colette Sirieix, Joëlle Riss, Véronique Naudet. Monitoring landfill cover by electrical resistivity tomography on an experimental site. Engineering Geology, 2012, 145-146, p. 18-29. 10.1016/j.enggeo.2012.06.002 . hal-00716361

\section{HAL Id: hal-00716361 https: / hal-brgm.archives-ouvertes.fr/hal-00716361}

Submitted on 10 Jul 2012

HAL is a multi-disciplinary open access archive for the deposit and dissemination of scientific research documents, whether they are published or not. The documents may come from teaching and research institutions in France or abroad, or from public or private research centers.
L'archive ouverte pluridisciplinaire HAL, est destinée au dépôt et à la diffusion de documents scientifiques de niveau recherche, publiés ou non, émanant des établissements d'enseignement et de recherche français ou étrangers, des laboratoires publics ou privés. 
1 MONITORING LANDFILL COVER BY ELECTRICAL RESISTIVITY

\section{TOMOGRAPHY ON AN EXPERIMENTAL SITE}

3

4

Fanny GENELLE ${ }^{\mathrm{a}, \mathrm{b}, *}$, SIRIEIX Colette $^{\mathrm{a}}$, RISS Joëlle ${ }^{\mathrm{a}}$, NAUDET Véronique ${ }^{\mathrm{a}, \mathrm{c}}$

${ }^{a}$ Univ. Bordeaux, I2M, UMR5295, F-33400 Talence, France ; fanny.genelle@u-bordeaux1.fr, colette.sirieix@u-bordeaux1.fr, joelle.riss@u-bordeaux1.fr, veronique.naudet@u-bordeaux1.fr

${ }^{\mathrm{b}}$ HYDRO INVEST, 514 route d'Agris, 16430 Champniers, France

${ }^{\mathrm{c}}$ Actually at BRGM, 3 avenue Claude Guillemin, 45060 Orléans, France

* Corresponding author. Université Bordeaux 1, Laboratoire GCE - I2M, Bâtiment B18, Avenue des facultés, 33400 Talence France ; Tel : (+33) 05400026 20, Fax : (+33) 054000 31 13, fanny.genelle@u-bordeaux1.fr

\section{Abstract}

In France, the monitoring of landfill cover after closure of the site is a local problem, since its tightness must be ensured over time. Leaks in the cover are a problem, as they allow water to infiltrate the stored waste. In order to locate such leaks, electrical resistivity tomography was used on an experimental site in which defects had been intentionally made in the cover. Repeated measurements taken on this site showed that the weather conditions preceding the measurements need to be taken into account, as they affect the water content in the cover material. They also showed that there are optimal weather conditions for detecting defects in the cover. A statistical analysis carried out on the electrical resistivity results for all surveys and cover material samples showed that the material was heterogeneous; this variability was mainly due to a difference in particle size (fines content) and in compaction. 
This study has shown the capacity of electrical resistivity tomography to detect defects and heterogeneity in the cover material, indicating that it is a good means of monitoring the quality of landfill cover both when it is put in place and subsequently.

Keywords: landfill cover, gravelly clay material, heterogeneity, compaction, electrical resistivity, multivariate analysis

\section{Introduction}

In France, the management of household waste is a local problem regarding the quantities of waste produced each year. Nearly half of it is stored in Municipal Solid Waste Landfills (MSW). These sites consist of several cells which are covered once they are full of waste. On its edges, this cover must have a slope of aroud $3 \%$ to facilitate water runoff. The law of 9 September 1997, published in the French journal officiel on 2 October 1997, made it obligatory to cover landfill so as to limit the infiltration of water into the waste; there is also an economic aspect, since the cost of treating leachates is high. The law was modified by the orders of 31 December 2001, 3 April 2002, 19 January 2006 and 18 July 2007. However, there are no French regulations concerning the composition of the cover. It is simply recommended to use clayey material which may be associated with geosynthetics (geomembranes or Geosynthetic Clay Liners), depending on the date of closure (Silvestre et al., 2003; ADEME, 2001). Over time, mechanical, climatic and hydraulic constraints may induce leaks in the cover. Indeed, the cover can be damaged during its installation. It is important to locate the damaged areas as they can cause an increase in the quantity of leachates in times of rain. 
Being non-destructive, geophysical methods could be a good way of detecting these anomalous zones. The use of electrical methods seems interesting for investigating the cover of landfills containing non-hazardous waste, for which few studies have been undertaken (Carpenter et al., 1991; Guyonnet et al., 2003; Ait Saadi, 2003). The electrical resistivity of a soil is a function of many properties (a synthesis of which was presented by Samouëlian et al. (2005)) such as compaction (Abu-Hassanein, 1996; McCarter, 1984), water content (Schwartz, 2008) and density of the material (Cosenza et al., 2010; Seladji et al., 2007; Besson et al., 2004) as well as temperature (Blewett, 2003; Rein et al., 2004; Hayley et al., 2007).

In order to study the behaviour of a loamy-clay cover material, an experimental site was established in which the effect of ageing was intentionally simulated through defects in the cover. The aim of our study was to test the ability of electrical resistivity methods to detect these defects and to characterise the heterogeneity of the cover material.

After the description of the study site, the electrical resistivity methods used to characterise the cover material are presented. The influence of the meteorological conditions (temperature and precipitations) was taken into account through the continuous recording of weather data near the site, as well as humidity and temperature data at various depths in the cover. Finally, the electrical resistivity models for the various surveys undertaken on the experimental site are presented. After observation of the varied behaviour of the cover, we carried out multivariate analysis on the electrical resistivity data of the gravelly-clay material. Finally, samples taken from the cover are described and interpreted.

\section{Material and methods}


2.1 Presentation of the experimental site

An experimental site was excavated with the aim of studying the behaviour of a landfill cover made up of $0.15 \mathrm{~m}$ of topsoil and one metre of reworked clayey material (Figure 1). The material was brought in from the town of Touvre en Charente (France), some $10 \mathrm{~km}$ distant, and had been excavated two months before being transported to the site. The material consisted of ancient alluviums made up, essentially, of silts and brown plastic clays. Laboratory tests such as methylene blue adsorption test (index about 5.5) and Atterberg limits (plasticity index $\mathrm{Ip} \approx 11 \%$ ) confirmed the loamy-clay nature of the material samples taken with the hand auger. However, the non-samplable sand and gravel observed in-situ lead us to qualify the material as gravelly clay, according to the GTR classification (NF P 11-300).

The material was put in place in three stages: the first layer of $40 \mathrm{~cm}$ and two other layers of $30 \mathrm{~cm}$ (referred to as Layer 1, Layer 2 and Layer 3 respectively in Figure 1). The experimental site was excavated in loamy alluvium, except for the north-west and south-east extremities, where the bedrock was backfilled (Figure 1). The material of each layer was levelled using the scoop of a 9-ton mechanical digger and then compacted by the caterpillar tracks of the mechanical digger as it was driven over the whole surface. The site building conditions have unfortunately not allowed to perform Proctor tests on the gravelly clay material. Moreover, because of the small size of the experimental site, the recommended slope of the cover has not been created. As the layers of gravelly clay material were put in place, so were cracks and material generally used for geodrains in landfill sites (Figure 1).

The three $2.5 \mathrm{~m}$-long cracks went through the thickness of the gravelly clay material cover, from -0.15 to $-1.15 \mathrm{~m}$ (Figures 1 and 2). They were made to simulate a construction defect or the consequences of deterioration by shrinkage and swelling of the cover material or 
100 by differential settling. The 4 and $10 \mathrm{~cm}$-wide cracks were filled with sand. Two geodrains,

$101 \mathrm{G} 1$ and G2, $8 \mathrm{~mm}$ wide and with an area of approximately 1 square metre, were placed, one 102 after the first layer of the cover was put in place, the other after the second layer (Figures 1 103 and 2).

Moisture probes (FDR type thetaprobes) and temperature probes (PT100) were also installed as the site was established (Figure 2) to record humidity and temperature over time. The site building conditions made it necessary to develop a procedure for correcting the moisture measurements after probes were put in place. As the hydric conditions of the cover material were constant during the 11 days between the beginning of recording on the 9 October 2009 and the first rain, it was estimated that the curves would be superimposed during this dry period. The a posteriori procedure was thus to check the consistency of each of the four curves during this period and to superimpose them, taking, as reference, the curve with values that corresponded to the humidity measurements taken in the laboratory on a 114 given date. station. tomography have been carried out using the Syscal Pro (IRIS Instruments) resistivity meter with various arrays (Wenner, Wenner-Schlumberger, gradient and dipole-dipole). Here, we 
present the results obtained using the dipole-dipole array, as it is the easiest to set up quickly on site, although the gradient array seemed more accurate. The $\mathrm{ERT}_{2}$ profile (Figure 3), consisting of 48 electrodes placed at intervals of $0.50 \mathrm{~m}$, crossed one of the two $10 \mathrm{~cm}$-wide cracks perpendicularly and passed directly over geodrain G1 situated at a depth of $0.75 \mathrm{~m}$. In order to eliminate any possibility of artefacts linked to the first measurements of the day, we took repeatable measurements by the successive acquisition of electrical resistivity data along the $\mathrm{ERT}_{2}$ profile (Peter-Borie et al., 2011). These measurements were taken with the dipoledipole array and did not present significant variation of electrical resistivity between the first measurements of the day and the following, allowing the measurements to be taken more quickly.

Measurements on other profiles were also taken over the whole site; the results were comparable to those of $\mathrm{ERT}_{2}$ (Genelle et al., 2010; Genelle et al., 2011) and are not presented here. A "control" line, $\mathrm{ERT}_{\mathrm{c}}$, (Figure 3) was set up on 8 February 2011, $1.20 \mathrm{~m}$ from $\mathrm{ERT}_{2}$ in a zone with no anomalies; samples of gravelly clay material were then taken along this profile in order to characterise its heterogeneity without affecting the site around the anomalies.

The apparent electrical resistivity of the various surveys was inverted with the RES2DINV(C software by means of a robust inversion (Loke et al., 2003) and model refinement. The resistivity models resulting from the inversion are presented as blocks. The true resistivity located in the cover were then corrected for temperature thanks to the data from the sensors on the experimental site (Figure 2). The position of these sensors make it possible to take into account the variation of temperature against depth; they were placed at depths of 0.10 and $0.15 \mathrm{~m}$ in the topsoil (sensors 5 and 6 in Figure 2) and at 0.35 and $0.70 \mathrm{~m}$ in the gravelly clay material (sensors 7 and 8 in Figure 2). We assumed that the temperatures 
recorded at each depth, far from any defect, would be representative of those in the whole material (top soil and gravelly clay) at the same depth.

Concerning the correction for temperature, various models allow the electrical resistivity values recorded at temperature $T$ (denoted as $\rho_{\mathrm{T}}$ ) to be adjusted to the reference temperature of $25^{\circ} \mathrm{C}$ (denoted as $\rho_{25}$ ) (Ma et al., 2010). The correction factor $\mathrm{f}_{\mathrm{T}}$ can be expressed by means of various functions: linear (Campbell et al., 1948), exponential (Sheets and Hendrickx, 1995; Lück et al., 2005; Corwin and Lesch, 2005) and power (Besson et al., 2008). Ma et al. (2010) compared these various expressions of the correction factor to measurements of electrical resistivity taken at various temperatures on soil samples and published in the Agriculture Handbook n ${ }^{\circ} 60$ (US Salinity Laboratory Staff, 1954). The expression $\rho_{\mathrm{T}}=\mathrm{f}_{\mathrm{T}} \times \rho_{25}=[0.4470+1.4034 \times \exp (-\mathrm{T} / 26.815)] \times \rho_{25}$, established by Corwin and Lesch in 2005 , is the one for which the residues calculated in relation to the data in the Agriculture Handbook, for temperatures of between 3 and $47^{\circ} \mathrm{C}$, are the lowest. So, it is this expression that is used here to correct the values of electrical resistivity.

\subsection{Monitoring precipitations, atmospheric temperature and humidity}

Study of the electrical resistivity measured over time on the experimental site required the current and preceding meteorological conditions to be taken into account. The data for effective rain (Figure 4. a) and atmospheric temperature (Figure 4. b) allow the classification of the surveys undertaken on the site according to the local meteorological conditions. To facilitate the use of these figures, the date of each geophysical survey is indicated in Figure 4 by a black line. 
According to the hydric conditions and temperature observed during the six surveys,

the measurements were classified in two periods, wet and dry. The wet period measurements were those taken on 2 and 10 February and 19 November 2010, when the rainfall accumulation was $60.3 \mathrm{~mm}$ in the month of January and $90.0 \mathrm{~mm}$ for the period 1 to 18 November 2010. These high levels of precipitations were linked to low atmospheric temperature, on average $2.8{ }^{\circ} \mathrm{C}$ during the surveys from 2 to 10 February and $8.4{ }^{\circ} \mathrm{C}$ during the survey of 19 November 2010.

The meteorological conditions observed at the time of the measurements taken in September 2010 differ from those of the three preceding surveys. During July, August and September, atmospheric temperatures were high (the monthly averages were respectively $21.8^{\circ} \mathrm{C}, 19.6^{\circ} \mathrm{C}$ and $16.5^{\circ} \mathrm{C}$ ) and there were negative effective rainfall accumulations (respectively $-113.3 \mathrm{~mm},-88.8 \mathrm{~mm}$ and $-64.0 \mathrm{~mm}$ ). This absence of effective rain led to a decrease in humidity in the gravelly clay material. The volumetric water content during the dry period at the time of this survey was $0.20 \mathrm{~m}^{3} \cdot \mathrm{m}^{-3}$ at a depth of $0.70 \mathrm{~m}$ (Figure $4 \mathrm{c}$.). This value contrasts with the higher one recorded during the wet period $\left(0.26 \mathrm{~m}^{3} \cdot \mathrm{m}^{-3}\right.$ corresponding to a humidity variation of $30 \%$ ).

The February 2011 measurements were taken in intermediary hydric conditions, between those of the two preceding periods. The humidity of $0.25 \mathrm{~m}^{3} \cdot \mathrm{m}^{-3}$ at a depth of $0.70 \mathrm{~m}$ was lower than that of February 2010. This value represents a reduction of about $4 \%$ and is linked to a rainfall accumulation that was four times lower in the month of January 2011 $(15.8 \mathrm{~mm})$ than in the preceding year $(60.3 \mathrm{~mm})$.

Although the volumetric water content of the gravelly clay material during the survey of 8 February 2011 was similar to that of 22 October $2009\left(0.23 \mathrm{~m}^{3} . \mathrm{m}^{-3}\right)$, these two surveys have to be studied separately. The October survey occurred after a single fall of rain $(19.3 \mathrm{~mm}$ on 20 September 2009) which took place after the experimental site was established, while the 
198 February 2011 survey took place after a series of episodes of light rain (on average, $2 \mathrm{~mm}$ per day) with an accumulation of effective rain of $3.6 \mathrm{~mm}$ one month before the survey.

After each of the three layers of gravelly clay material was put in place, electrical mapping was carried out using $2 \mathrm{~m}$ mesh made up of six parallel lines arranged in a northwest south-east direction. The measurements were taken with a Schlumberger array $(\mathrm{AB} / 2=0.50 \mathrm{~m}$ and $\mathrm{MN} / 2=0.10 \mathrm{~m})$ thanks to a device developed by HYDRO INVEST. Between the 8 and 14 September 2009, the cover material was put in place and the resistivity measurements were taken.

The measurements of apparent electrical resistivity were then inverted on the basis of a two-layer model in which the true resistivity of the alluvium and subjacent anthropogenic deposits (Figure 1) were known thanks to an electrical resistivity tomography profile established on the excavated area before the cover was put on. The values of true resistivity obtained with the formula of Bhattacharya and Patra (1968) were corrected for the effect of temperature on the assumption that the measurements had been influenced by atmospheric temperature alone (the average value of the atmospheric temperature data from the meteorological station near the site between the 4 and 21 September 2009). The gravelly clay material was considered to be in equilibrium with the atmospheric temperature, the excavation

218 and storage having been done two months previously. With these data, iso-resistivity maps 219 were established for each of the three layers of material at the moment that they were put in place. These maps were the result of interpolation by kriging with a search ellipse radius of $4 \mathrm{~m}$ using the SURFER software. One of the maps is presented in Figure 16; it is based on 
kriging interpolation with an exponential and quadratic model fitted to the omni-directional experimental variogram.

\section{Results}

\subsection{Detection of the $10 \mathrm{~cm}$-wide crack}

The models of electrical resistivity for the $\mathrm{ERT}_{2}$ profile (Figure 5) presented values of electrical resistivity that were not corrected for the effect of temperature during the six series of measurements from October 2009 to February 2011. The range of electrical resistivity on the site and its bedrock varied, overall, between 10 and $113 \Omega$.m. On each profile except that of September 2010 (Figure 5. d.), there were two large areas: one was superficial and conductive (electrical resistivity lower than $50 \Omega . \mathrm{m}$ ) and the other was deep and resistive (electrical resistivity between 50 and $113 \Omega . \mathrm{m}$ ). The boundary between these two areas along $\mathrm{ERT}_{2}$ was located at a distance of between 2 and $17.5 \mathrm{~m}$ and a depth of $1.15 \mathrm{~m}$; it continued beyond $17.5 \mathrm{~m}$, gradually rising to the surface as the cover became shallower. So, this change in electrical resistivity took place at a depth corresponding to the total thickness of the experimental cover. The conductive area was thus that of the gravelly clay material and the resistive area that of the bedrock (Figure 1). Also, we observed, on all the models of electrical resistivity, a decrease in resistivity in the bedrock between 3 and $6 \mathrm{~m}$. The decrease in the resistivity for the measurements with the dipole-dipole array was not found in the results achieved with the other arrays. We therefore suppose that it was caused by an artefact introduced when inverting the measurements taken by the dipole-dipole array; the artefact was verified by forward modelling. There was also a significant increase in electrical resistivity at a distance of about $4 \mathrm{~m}$ along the profile, except for that of September 2010 
(Figure 5.d), over a thin slice through the entire thickness of the cover. This increase in

248 resistivity appeared at the $10 \mathrm{~cm}$-wide crack that was filled with sand (Figure 3). This

249 resistivity of more than $100 \Omega . \mathrm{m}$ can thus be interpreted as being the signature of the crack,

250 below $0.15 \mathrm{~m}$ of top soil. For deeper cracks, forward modeling computed with the

251 RES2DMOD॰ (Loke, 2002) software have shown that electrical resistivity tomography

252 would be able to detect these cracks (not shown here).

253 The $10 \mathrm{~cm}$-wide crack was, however, not easily detected on the resistivity model for

254 September 2010 (Figure 5. d) which presented, for the central part of the cover material,

255 higher electrical resistivity (between 30 and $113 \Omega . \mathrm{m}$ ). The contrast of resistivity between the

256 crack and the rest of the cover was no longer perceptible with the range of electrical resistivity

257 used; nevertheless, the true electrical resistivity at the place of the crack raised about $258600 \Omega . m$.

The presence, on the surface, of electrical resistivity greater than $80 \Omega . m$ (Figure 5. d) should be seen in the light of the high atmospheric temperatures recorded during the summer

261 (Figure 4.b.) which helped to dry the ground. Indeed, many cracks caused by drying, some of which were at least $36 \mathrm{~cm}$ deep, were observed during dry periods. These cracks no longer appeared during the later surveys undertaken during the wet period.

Apart from the September 2010 survey, the analysis of electrical resistivity not corrected for temperature for all the surveys led to the detection of the $10 \mathrm{~cm}$-wide crack. Moreover, spatial variations in electrical resistivity within the gravelly clay cover were detected and seemed to persist over the course of the surveys. So, in order to characterise as well as possible this variability, it was necessary to correct the electrical resistivity for the effect of temperature in order to make the models comparable. 
Once the values were corrected, they were found to be between 10 and $40 \Omega$.m (Figure 6) except for those of September 2010; a detailed examination revealed a spatial organisation that persisted from one ERT to the next.

As from the measurements taken in October 2009 (Figure 6. a.), one can see a spatial organisation of electrical resistivity along the $\mathrm{ERT}_{2}$ profile. Three particularly conductive zones (A, B and C, with resistivity of between 10 and $20 \Omega . \mathrm{m}$ ), were thus brought to light. The distribution of these low values of electrical resistivity was similar for the data acquired in wet periods ( 2 and 10 February and 19 November 2010, Figures 6 b., c. and e.). These zones nevertheless seemed smaller on 8 February 2011 (Figure 6 f.); this reduction in extension was linked to an increase in electrical resistivity in the superficial part of the cover material (between 0 and $0.25 \mathrm{~m}$ in depth). An analysis of precipitations over the seven days before 8 February 2011 shows that the effective rainfall accumulation was $-2.8 \mathrm{~mm}$, while in wet periods it was $6.5 \mathrm{~mm}$ on 2 February, $29.4 \mathrm{~mm}$ on 10 February and $27.1 \mathrm{~mm}$ on 19 November 2010. The extension of zones A, B and C decreased from 2 February 2010 to 8 February 2011; this was particularly obvious for zone A.

It is interesting to note the variations in electrical resistivity in the superficial part of the cover material in the measurements taken at a close interval, on 2 and 10 February 2010 (Figures $6 \mathrm{~b}$. and c.). The resistivity at between 5 and $20 \mathrm{~m}$ horizontal distance and to a depth of $0.25 \mathrm{~m}$ were lower for the measurements of 10 February 2010. The average of these values was $30.8 \Omega . m$ on 2 February (with a minimum of $17.7 \Omega . m$ ) and $26 \Omega$ m on 10 February (with a minimum of $13.6 \Omega$.m). In fact, the precipitations' accumulation over the seven preceding days was different for each of these two surveys; it was $29.4 \mathrm{~mm}$ for the 10 February and only $6.5 \mathrm{~mm}$ for the 2 February 2010. Consequently, the differences of electrical resistivity in the superficial part of the gravelly clay material could be, a priori, due to variations of humidity in 
the cover, themselves linked to the precipitations preceding the measurements in a period that was generally wet.

We noted a certain consistency in the spatial distribution of electrical resistivity in the gravelly clay material, except in the month of September 2010. The change in electrical resistivity over time in the various zones depends on the frequency and intensity of precipitations preceding the measurements and, therefore, on the conditions of humidity at the time of the surveys. we used multivariate analysis (ascendant hierarchical classification, $\mathrm{ACH}$ ). The clustering of 164 standardized variables of electrical resistivity at between 5 and $19 \mathrm{~m}$ and depths of between 0.26 and $0.76 \mathrm{~m}$ for the six series of measurements was done using the Ward linkage method together with a Euclidian distance measure. The electrical resistivity data for the blocks situated on the upper and lower levels of the gravelly clay material, as well as those of the four blocks situated at between 18 and $19 \mathrm{~m}$ and at a depth of $0.76 \mathrm{~m}$ were not taken into account because of the influence of the top soil on the surface and by the deeper, bedrock. ACH (Figure 7) permits the identification of four clusters of electrical resistivity values. notes the greater proximity of clusters 2 and 3 which constitute $52 \%$ of the data at a distance of 25.22 (Figure 7). For clusters 1 and 4, the distance is greater (38.70), showing their greater variability. It is then possible to analyse by cluster and by date of measurement thanks to the 
calculation of the statistical parameters, in particular the median and the standard deviation of the data (Table 1).

In order of increasing median values of electrical resistivity and for all dates of measurement, the clusters have the following order: 1-4-2-3. The values for clusters 1 and 4 are the lowest: they vary, respectively, from 14.0 to $17.3 \Omega . \mathrm{m}$ and from 18.0 to $21.3 \Omega . \mathrm{m}$ in the wet period (Table 1). For clusters 2 and 3, the values were higher: they were, respectively, between 19.7 and $22.5 \Omega . \mathrm{m}$ and between 22.9 and $25.3 \Omega . \mathrm{m}$ in the wet period. The values confirm that clusters 2 and 3 are closer to each other than are clusters 1 and 4 . Also, the ratio of the standard deviation to the median (Table 1) shows that the variations in electrical resistivity are of greater amplitude for clusters 1 and 3 than for clusters 4 and 2, in particular for the survey of September 2010. Cluster 1 contains the lowest, and cluster 3 the highest, values of electrical resistivity.

It is also interesting that the changes in the electrical resistivity of the four clusters develop in a similar way over time (Figure 8). Indeed, the resistivity reduces all the more when measurements are carried out during wet periods, with the exception of 22 October 2009 (Figure 4 a.). For that date, the resistivity values cannot be considered as representative of the conditions of humidity in the material as the site had been established only one month before.

study of their spatial distribution allows us to note, for each block, the cluster to which it belongs (for each of the six surveys) (Figure 9). The zones delimited by each cluster correspond overall to the previously identified zones A, B and C. 
3.4 Heterogeneity characterisation of the gravelly-clay material

In order to determine the geotechnical characteristics of each of the four clusters, samples of material were taken along $\mathrm{ERT}_{\mathrm{c}}$. Only the loamy clay component of the material could be taken with the hand auger. First, the clusters determined by ACH carried out on the data from $\mathrm{ERT}_{2}$ were re-attributed to each of the blocks forming the resistivity model of $E T_{c}$. It was thus possible to compare the statistical parameters of ERT $T_{c}$ profile to those of $\mathrm{ERT}_{2}$ for the five series of measurements (Table 2); the values for September 2010 (a dry period) are not considered. both present a low localised electrical resistivity in the 5 to $8 \mathrm{~m}$ zone.

The four samples of loamy clay material were taken from zones with values of electrical resistivity (Figure 10 b.) corresponding to the clusters defined by multivariate 
analysis. Samples $E_{1}$ and $E_{10}$ correspond, respectively, to clusters 1 and 4 , and $E_{6}$ and $E_{14}$ to clusters 3 and 2 (Figure 11).

In order to characterise the loamy clay material from each of the four samples, laboratory analysis was undertaken, to measure the gravimetric water content (Table 3) and to establish the particle size distribution curve (Figure 12) of each of the samples.

The values of gravimetric water content (Table 3) were found to be between 21.5 and 28.0\%. Samples $\mathrm{E}_{1}$ and $\mathrm{E}_{10}$, having a water content of 28.0 and $26.5 \%$ respectively, corresponded to clusters 1 and 4 . These two clusters presented the lowest electrical resistivity values (the median value of electrical resistivity for these two clusters was respectively 17.4 and $19.7 \Omega . m)$. For the other two samples $\left(\mathrm{E}_{14}\right.$ and $\left.\mathrm{E}_{6}\right)$, the gravimetric water content was respectively 21.5 and $23.5 \%$. The samples came from zones attributed to clusters 2 and 3 which presented median values of electrical resistivity of, respectively, 21.6 and $22.6 \Omega . m$. One sees here the inversion of electrical resistivity in relation to the values of gravimetric water content; this can be explained by the proximity of clusters 2 and 3 seen in the dendrogram (Figure 7).

The samples were then sieved in order to establish the particle size distribution curves (Figure 12). The curves show differences in the gravimetric percentage for fractions with a grain size of between 80 and $400 \mu \mathrm{m}$ : the percentage of fines is seen to be greater than $80 \%$ for samples $E_{1}$ and $E_{10}$ and lower than $80 \%$ for samples $E_{6}$ and $E_{14}$.

We can also note that the four gravelly clay samples characterised by different fines content are placed at the location of electrical resistivity variations on the $\mathrm{ERT}_{\mathrm{c}}$ model (Figure 13). It can also be noted that the proportion of fines in the loamy clay component of the material is in direct relation to the gravimetric water content (Figure 14). 


\section{Discussion}

The geotechnical parameters (gravimetric water and fines content) recorded for the samples can be studied in relation to the median values of the electrical resistivity of the four clusters in $\mathrm{ERT}_{\mathrm{c}}$ (Figure 15). The graphs show that the median values of resistivity rise to an optimum peak and then decrease in direct relation to the gravimetric water content (Figure 15 a.) and the percentage of fines (Figure 15 b.). However, taking into account the proximity of clusters 2 and 3, which are already visible in the dendrogram (Figure 7) and of the low deviation of electrical resistivity between these two clusters in $\mathrm{ERT}_{\mathrm{c}}$ (Table 2), one can consider that the electrical resistivity tends to decrease with the content of gravimetric water and of fines. We will deal with the effect of compaction on electrical resistivity first, and then with that of the meteorological conditions.

The analysis of the samples has thus shown that the electrical resistivity of the different clusters is related to the heterogeneity of the cover material. This variability seems to be linked to both the gravimetric water content and the percentage of fines; and knowing that the electrical resistivity is also linked to compaction (Beck et al., 2008), we sought to demonstrate the effect of compaction while taking into account the intrinsic heterogeneity of the material. To do this, we used the map of electrical resistivity on the surface of layer 2 (Figure 16). This map shows a central area of low resistivity (lower than $30 \Omega . \mathrm{m}$ ) and a peripheral area of more resistive material (most of the measurements of resistivity being between 30 and $50 \Omega . \mathrm{m}$ ). The differences in electrical resistivity can be put in relation to the effect of the mechanical digger: indeed, while the digger did pass regularly over the central area, this was not the case for the periphery of the site, where access was more difficult. So, 
the lower values of resistivity could be linked to greater compaction. The differences in electrical resistivity revealed by the ERT imaging and in Figure 16 are similar: the resistivity of clusters 1 and 4 corresponds to a conductive zone of the map in Figure 16, while the electrical resistivity of cluster 2 corresponds to the resistive zone. Clusters 1 and 4, well individualised by the imaging, are thus well characterised by a finer particle size and a more obvious compaction. The coherence of the spatial distribution of the electrical resistivity, in the tomography imaging as well in the resistivity map (Figure 16), is due to both the intrinsic heterogeneity of the material and the effect of compaction. monitoring of the volumetric water content over time at a depth of $0.70 \mathrm{~m}, 2 \mathrm{~m}$ north of $\mathrm{ERT}_{2}$ profile (Figure 2). The monitoring of electrical resistivity along $\mathrm{ERT}_{2}$ profile allowed us to relate decreasing median values of electrical resistivity of each of the four clusters to increasing volumetric water content (Figure 17). Even though the values of volumetric water content cannot be directly compared to the values of gravimetric water content of the samples, one can nevertheless see a tendency for electrical resistivity to decrease with increasing volumetric water content. The transition between high resistivity (dry period) and low resistivity (wet period) can be represented either by two different straight lines or by an exponential, as suggested by Russel et al. (2010), with measurements of gravimetric water content. To clarify this decrease, further measurements are currently being taken. Here again, 440 it can be noted that the greater proximity of clusters 2 and 3, observed particularly on 27 441 September 2010, would seem to indicate that these two clusters could well be classified as a 442 single cluster.

\section{Conclusions}


Electrical resistivity tomography was carried out on an experimental site in order to determine the capacity of this method to locate fabricated defects and to characterise the heterogeneity of the cover material. The surveys, carried out at different periods in the year, showed that electrical resistivity tomography provided satisfactory results over almost the whole year. Detection of anomalies was easier when the inspection took place in a wet period and was more difficult, or even impossible, in a dry period. In favourable meteorological conditions, the $10 \mathrm{~cm}$-wide crack which simulated an ageing defect was clearly identified with an inter-electrode spacing of $0.50 \mathrm{~m}$. The heterogeneity of the cover material was demonstrated by each of the surveys in the wet period. Indeed, variations in electrical resistivity, once corrected for temperature, remain in the gravelly clay material, underlining the existence of different modes of behaviour. The multivariate analysis $(\mathrm{ACH})$ carried out on the electrical resistivity of the cover material for the different dates of measurement permitted

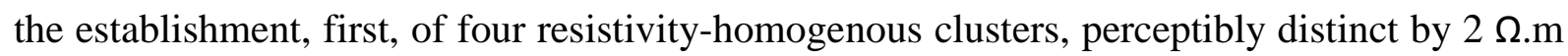
in the wet period; and secondly, putting the ERT model blocks into clusters highlighted the that they were linked to the statistical characteristics of the clusters. In addition, the to be taken into account when establishing the cover. However, while the permeability of the cover material depends mainly on its particle size, it also depends on its state of compaction. 
tightness over time. This study has shown that the use of electrical resistivity tomography can allow the characterization of the heterogeneity of the cover. The monitoring, over time, of electrical resistivity has also shown that the state of the soil in dry periods, with the appearance of cracks in the gravelly clay material, jeopardizes the tightness of the cover in these periods. Nevertheless, the closing up of cracks in wet periods was observed, both visually and by tomography. These observations lead us to recommend the use of electrical resistivity tomography in wet periods, which favour the detection of defects. Also, to avoid cracking in the cover material, it would be useful to sprinkle the cover in dry periods so as to limit the appearance of zones liable to water infiltration.

\section{Acknowledgements}

We wish to thank Stéphane Renié for its help in setting up the experimental site and also Fabien Naessens for the electrical resistivity tomography measurements. We also thank l'Agence de l'Environnement et de la Maîtrise de l'Energie (ADEME) and most particularly Philippe Bégassat for his collaboration in this study.

\section{References}

Abu-Hassanein, Z.S., Benson, C.H., Blotz, L.R., 1996. Electrical resistivity of compacted clays. Journal of Geotechnical Engineering, 122(5), 397-406.

ADEME, 2001. Guide pour le dimensionnement et la mise en œuvre des couvertures de sites de stockage de déchets ménagers et assimilés. 167 pp.

Ait Saadi, L., 2003. Méthodologie de contrôle de l'homogénéité et de la perméabilité des barrières argileuses. Thèse de $3^{\text {ème }}$ cycle. Université Paris VI. 
Bhattacharya, P.K., Patra, H.P., 1968. Direct current geoelectric sounding. Elsevier, Amsterdam, New York, London.

497

498

Beck, Y-L., Palma-Lopes, S., Ferber, V., Ech-Charhal, Y., Fauchard, C., Guilbert, V., Froumentin, M., Côte, P., 2008. Détermination de l'état hydrique et de la masse volumique d'un sol limoneux par combinaison de méthodes géophysiques : du laboratoire au site contrôlé. Journées Scientifiques de Géophysique Appliquée. Aix en Provence.

Besson, A., Cousin, I., Samouëlian, A., Boizard, H., Richard, G., 2004. Structural heterogeneity of the soil tilled layer as characterized by 2D electrical resistivity surveying. Soil and Tillage Research, 239-249.

Besson, A., Cousin, I., Dorigny, A., Dabas, M., King, D., 2008. The temperature correction for the electrical resistivity measurements in undisturbed soil samples: Analysis of the existing conversion models and proposal of a new model. Soil Science, 173, 707-720.

Blewett, J., Mc Carter, W.J., Chrisp, T.M., Starrs, G., 2003. An experimental study on ionic migration through saturated kaolin. Engineering Geology, 70, 281-291.

Campbell, R. B., Bower, C. A., Richards, L. A., 1948. Change of electrical conductivity with temperature and the relation of osmotic pressure to electrical conductivity and ion concentration for soil extracts. Soil Science Society of America Proceedings, 13, 6669.

Carpenter, P.J., Calkin, S.F., Kaufmann, R.S., 1991. Assessing a fractured landfill cover using electrical resisitivty and seismic refraction techniques. Geophysics, 56(13), 18961904.

Cosenza, P., Seladji, S., Besson, A., Cousin, I., Goutal, N., Boizard, H., Tabbagh, A., Ranger, J., Richard, G., 2010. Caractérisation géoélectrique in situ du compactage des sols 
agricoles et forestiers. Journées Nationales de Géotechnique et de Géologie de l’Ingénieur. Grenoble.

Corwin, D. L., Lesch, S. M., 2005. Apparent soil electrical conductivity measurements in agriculture. Computers and Electronics in Agriculture, 46, 11-43.

Genelle, F., Sirieix, C., Naudet, V., Dubearnes, B., Riss, J., Naessens, F., Renié, S, Trillaud, S., Dabas, M, Bégassat, P., 2010. Test de méthodes géophysiques sur couvertures de CSD : site expérimental. Journées Nationales de Géotechnique et de Géologie de l’Ingénieur. Grenoble.

Genelle, F., Sirieix, C., Naudet, V., Riss, J., Naessens, F., Renié, S., Dubearnes, B., Bégassat, P., Trillaud, S., Dabas, M., 2011. Geophysical methods applied to characterize landfill covers with geocomposite. In: GEOFRONTIERS, 13-16 March 2011, Dallas. ASCE Conf. Proc., doi:10.1061/41165(397)199.

Guyonnet, D., Gourry, J.-C., Bertrand, L., Amraoui, N., 2003. Heterogeneity detection in an experimental clay liner. Canadian Geotechnical Journal, 40, 149-160, doi: 10.1139/T02-092.

Hayley, K., Bentley, L.R., Gharibi, M., Nightingale, M., 2007. Low temperature dependence of electrical resistivity: Implications for near surface geophysical monitoring. Geophysical Research Letters 34, L18402, doi:10,1029/2007GL031124.

Journal Officiel de la République Française (2 octobre 1997). Arrêté du 9 septembre 1997 relatif aux décharges existantes et aux nouvelles installations de stockage de déchets ménagers et assimilés.

Loke, M.H. 2002. RES2DMOD version 3.01. Rapid 2D resistivity forward modelling using the finite difference and finite-element methods.

Loke, M.H., Acworth, I., Dahlin, T., 2003. A comparison of smooth and blocky inversion methods in 2D electrical imaging surveys. Exploration Geophysics, vol. 34, 182-187. 
Lück, E., Rühlmann, J., Spangenberg, U., 2005. Physical background of soil EC mapping: Laboratory, theoretical and field studies. In J. V. Stafford (Ed.), Precision agriculture’05 (pp. 417-424). The Netherlands: Wageningen Academic Publishers.

Ma, R., McBratney, A., Whelan, B., Minasny, B., Short, M., 2010. Comparing temperature correction models for soil electrical conductivity measurement. Precision Agriculture, 12, 55-66 doi :10,1007/s11119-009-9156-7.

McCarter, W.J., 1984. The electrical resistivity characteristics of compacted clays. Geotechnique, 34(2), 263-267.

NF P 11-300, septembre 1992. Classification des matériaux utilisables dans la construction des remblais et des couches de forme d'infrastructures routières.

Peter-Borie, M., Sirieix, C., Naudet, V., Riss, J., 2011. Electrical resistivity monitoring with buried electrodes and cables: noise estimation with repeatability test. Near Surface Geophysics, 9, 12 pp.

Rein, A., Hoffmann, R., Dietrich, P., 2004. Influence of natural time-dependent variations of electrical conductivity on DC resistivity measurements. Journal of Hydrology, 285, $215-232$.

Russell, E.J.F, Barker, R.D., 2010. Electrical properties of clay in relation to moisture loss. Near Surface Geophysics, 8, 173-180, doi:10,3997/1873-0604,2010001.

Samouëlian, A., Cousin, I., Tabbagh, A., Bruand, A., Richard, G., 2005. Electrical resistivity survey in soil science : a review. Soil \& Tillage research, 83, 173-193.

Schwartz, B.F., Schreiber, M.E., Yan, T., 2008. Quantifying field-scale soil moisture using electrical resistivity imaging. Journal of Hydrology, 362, 234-246.

Seladji, S., Cosenza, P., Richard, G. Tabbagh, A., 2007. Mesure et modélisation des variations de résistivité électrique d'un sol limoneux liées au tassement. $6^{\text {ème }}$ colloque GEOFCAN, Bondy. 
569 Sheets, K.R., Hendrickx, J.M.H., 1995. Non-invasive soil water content measurement using electromagnetic induction. Water Resource Research, 31, 2401-2409.

571 Silvestre, P., Norotte, V., Oberti, O., 2003. Les géosynthétiques en couverture. $5^{\text {ème }}$ rencontres 


\section{FIGURES}
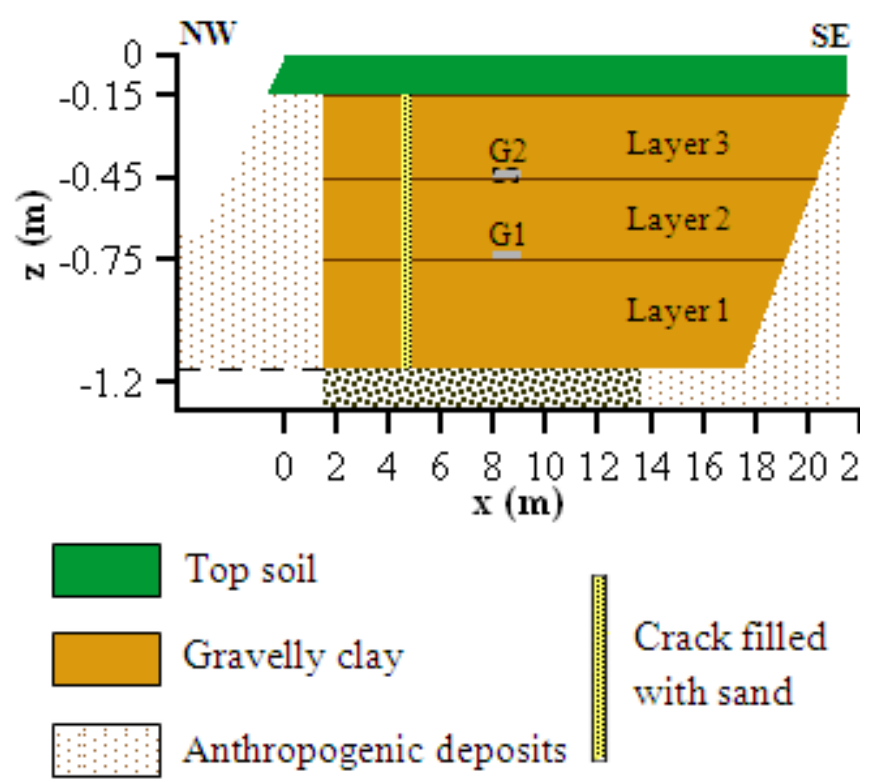

\% Loamy alluvium $=$ Geodrain

Figure 1: Section of the experimental site

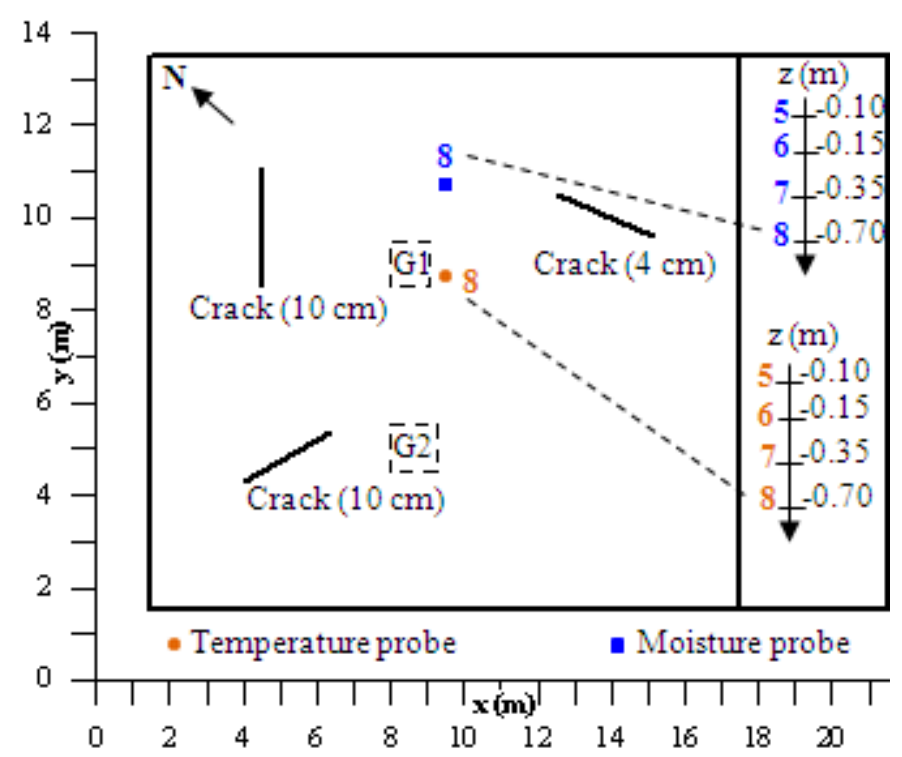

Figure 2: Location of defects intentionally made and probes in the experimental site 


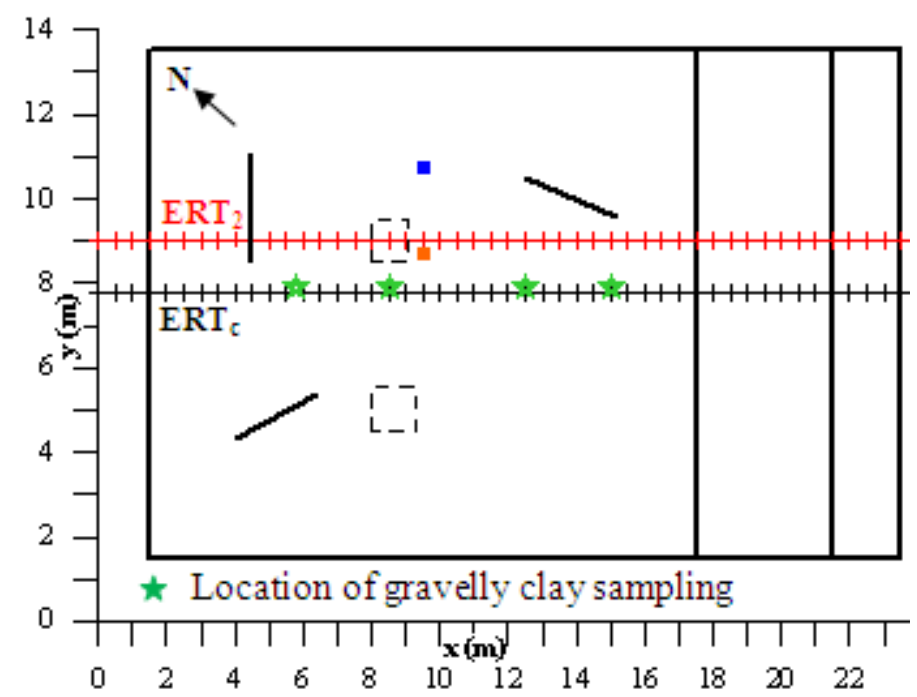

Figure 3: Location of electrical resistivity tomography profiles on the experimental site 


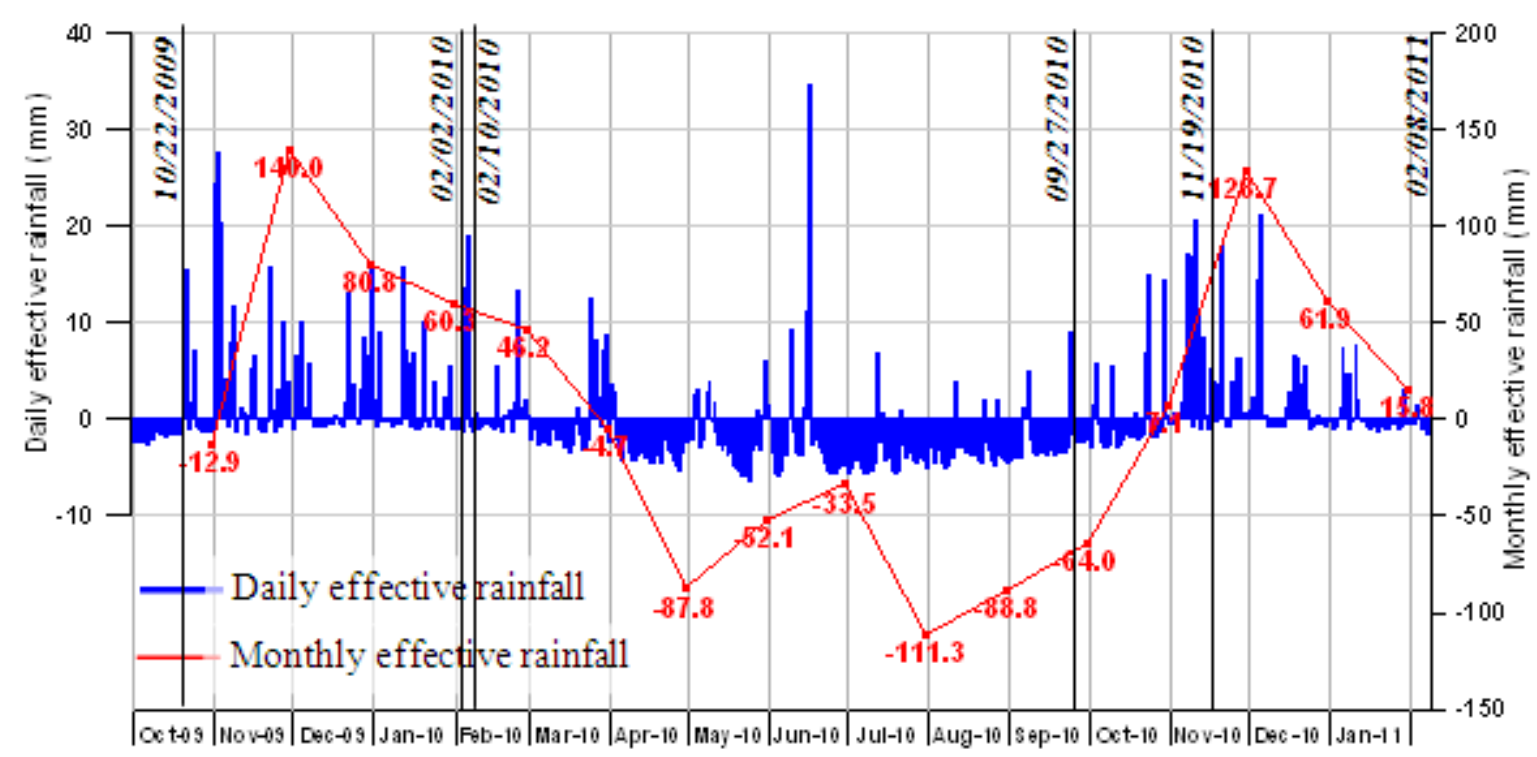

a) Daily and monthly effective rainfall

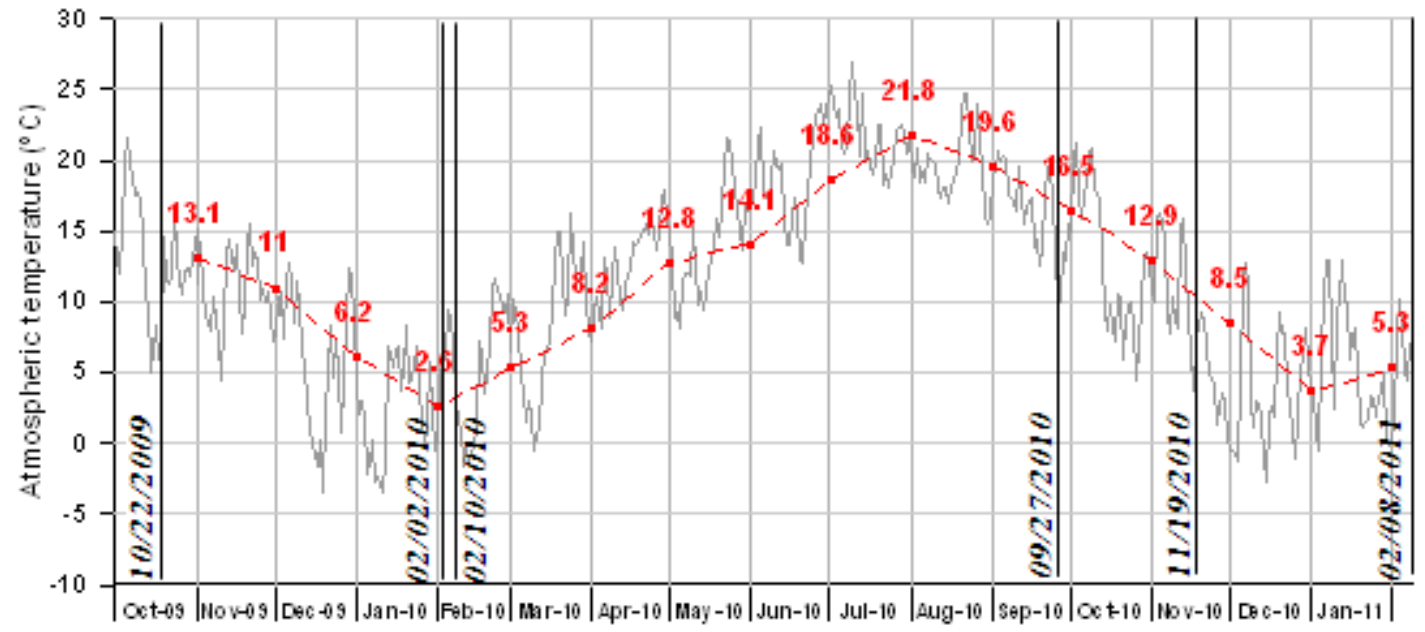

b) Mean daily and monthly atmospheric temperature

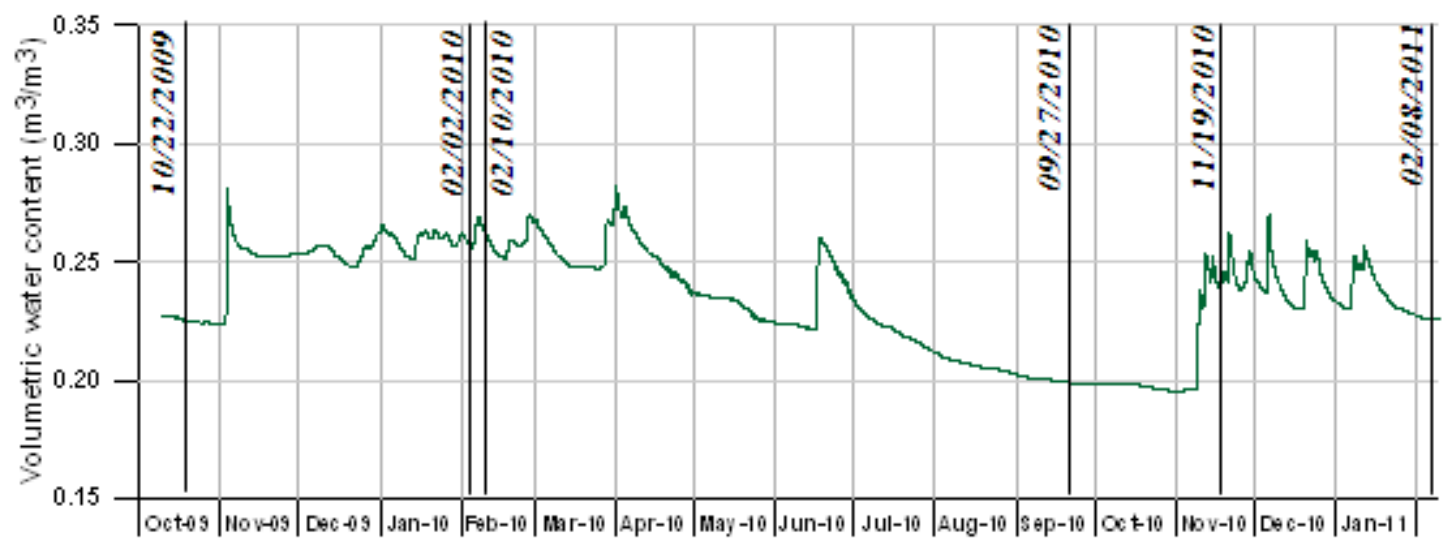

c) Volumetric water content at a depth of $0.70 \mathrm{~m}$ (probe $\mathrm{n}^{\circ} 8 \mathrm{in}$ Figure 2)

Figure 4: Data for effective rain and atmospheric temperature near the experimental site and humidity data in the gravelly clay material (from October 2009 to February 2011) 


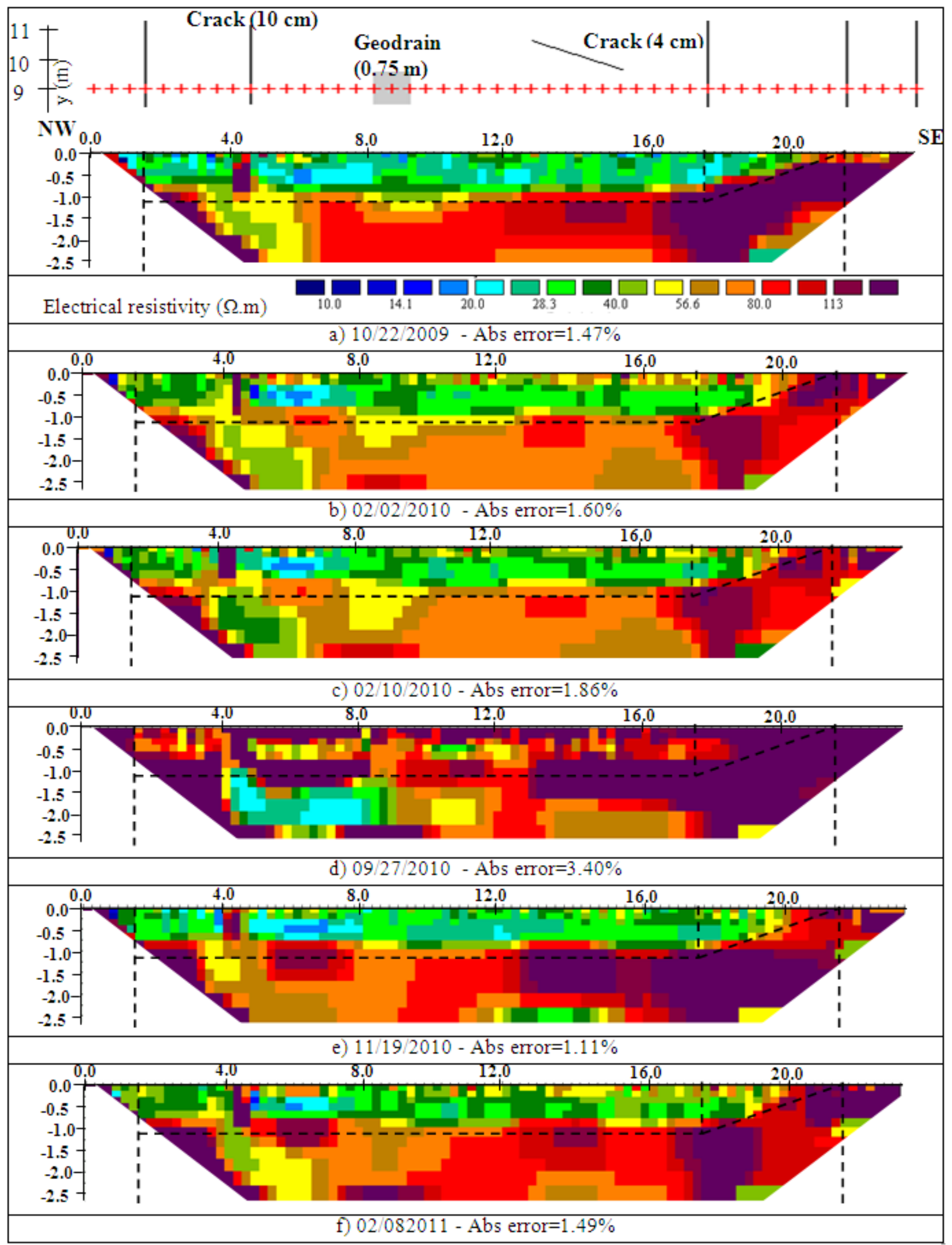

Figure 5: Models of electrical resistivity (not corrected for temperature) of $\mathrm{ERT}_{2}$ profile after five iterations (model block cells) 


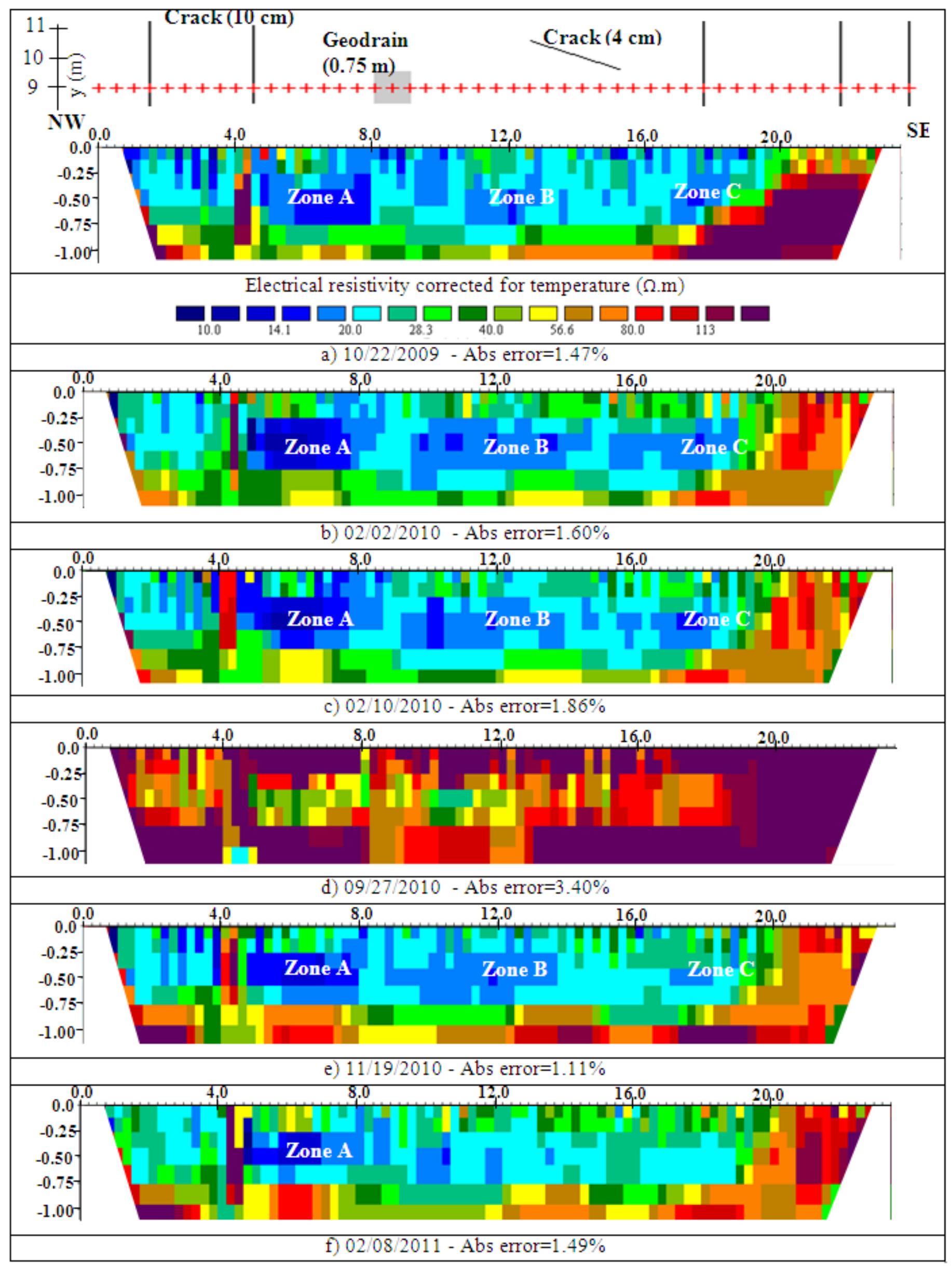

Figure 6: Models of electrical resistivity corrected for temperature in the cover along $\mathrm{ERT}_{2}$ profile (model block cells) 


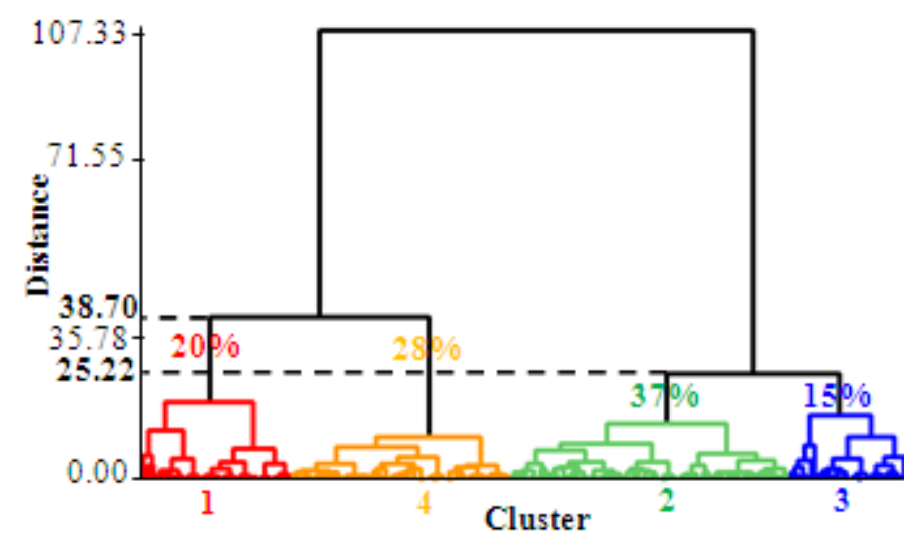

Figure 7: Dendrogram of the standardized variables of electrical resistivity corrected for temperature in the six surveys along $\mathrm{ERT}_{2}$ with the percentage of blocks in each cluster

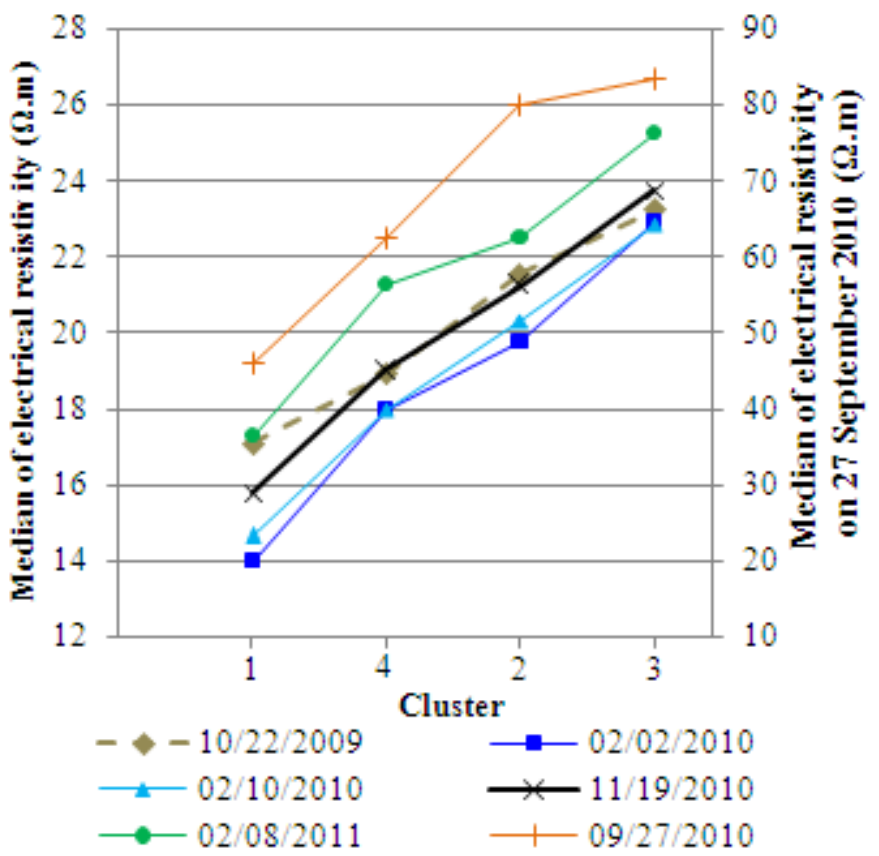

Figure 8: Median of electrical resistivity corrected for temperature, by cluster and date of survey 


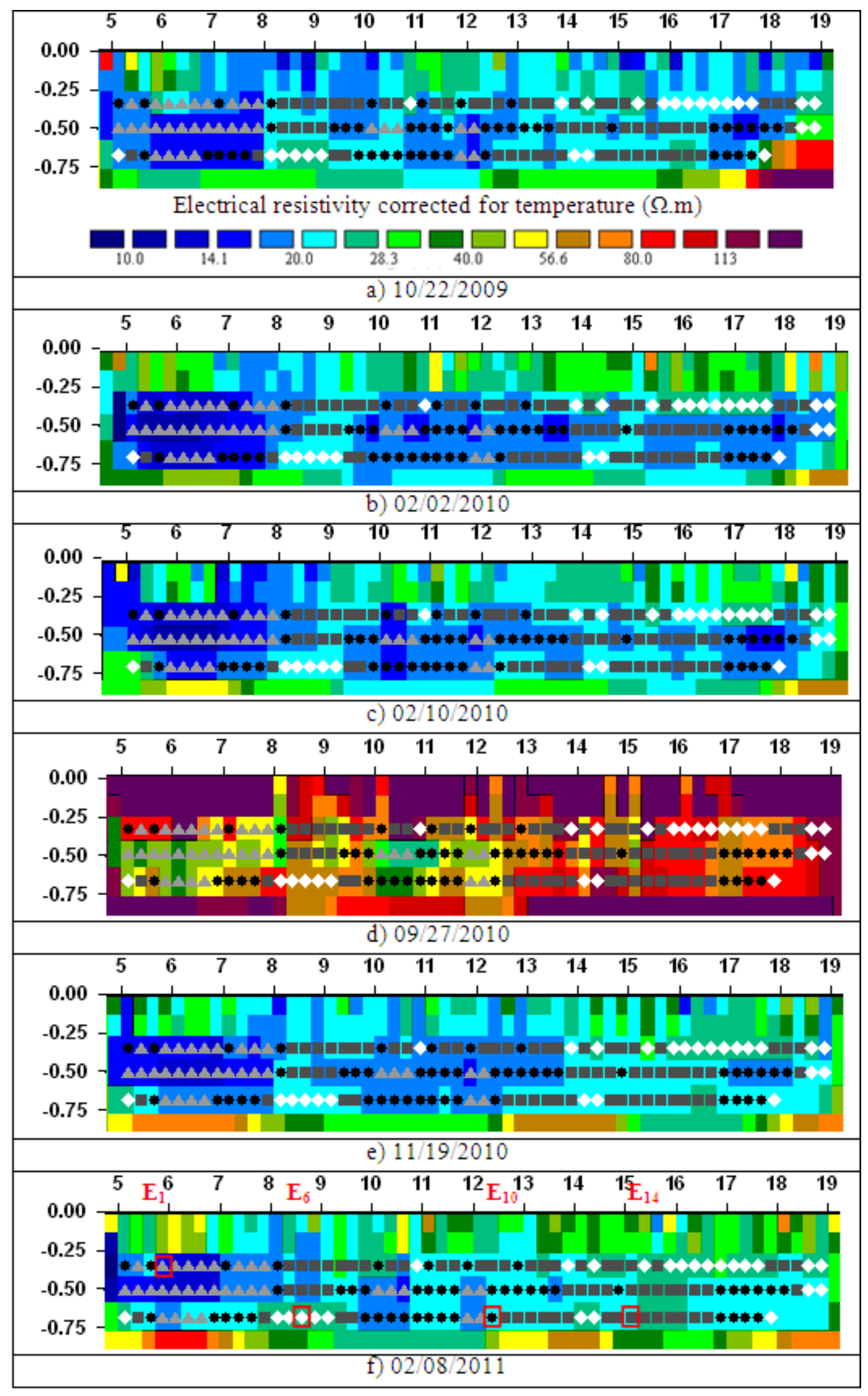
$\Delta$ Cluster 1
Cluster 2
$\diamond$ Cluster 3
Cluster 4

Figure 9: Spatial distribution of the clusters of electrical resistivity as determined by multivariate analysis along the $\mathrm{ERT}_{2}$ profile 


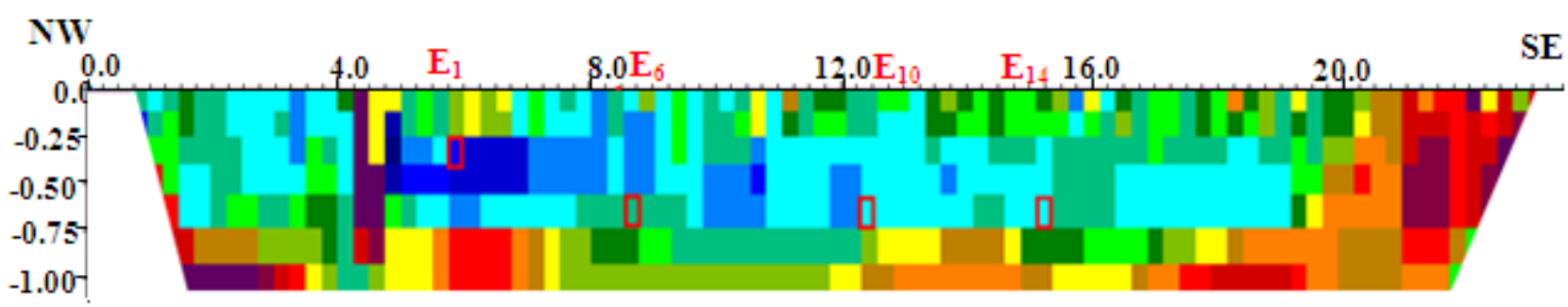

a) $\mathrm{ERT}_{2}$ profile

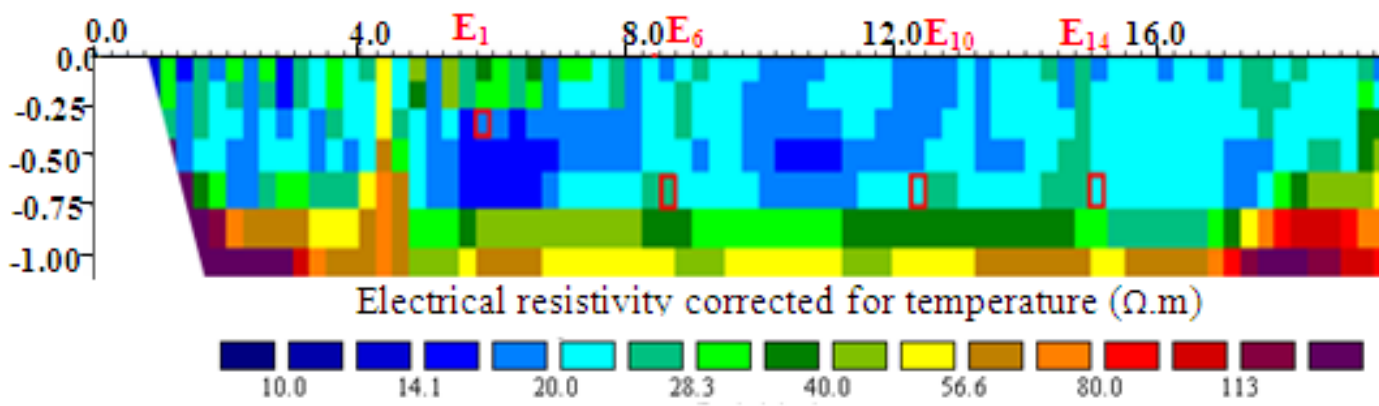

b) $\mathrm{ERT}_{\mathrm{c}}$ profile

Figure 10: Models of electrical resistivity corrected for temperature in the cover on 8 February 2011 (model block cells)

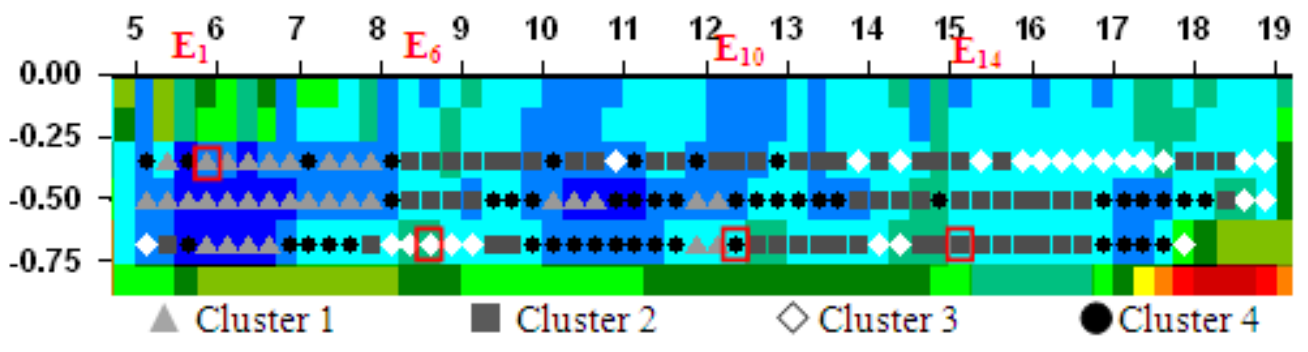

Figure 11: Spatial distribution of clusters of electrical resistivity established by multivariate analysis along profile $\mathrm{ERT}_{\mathrm{C}}$

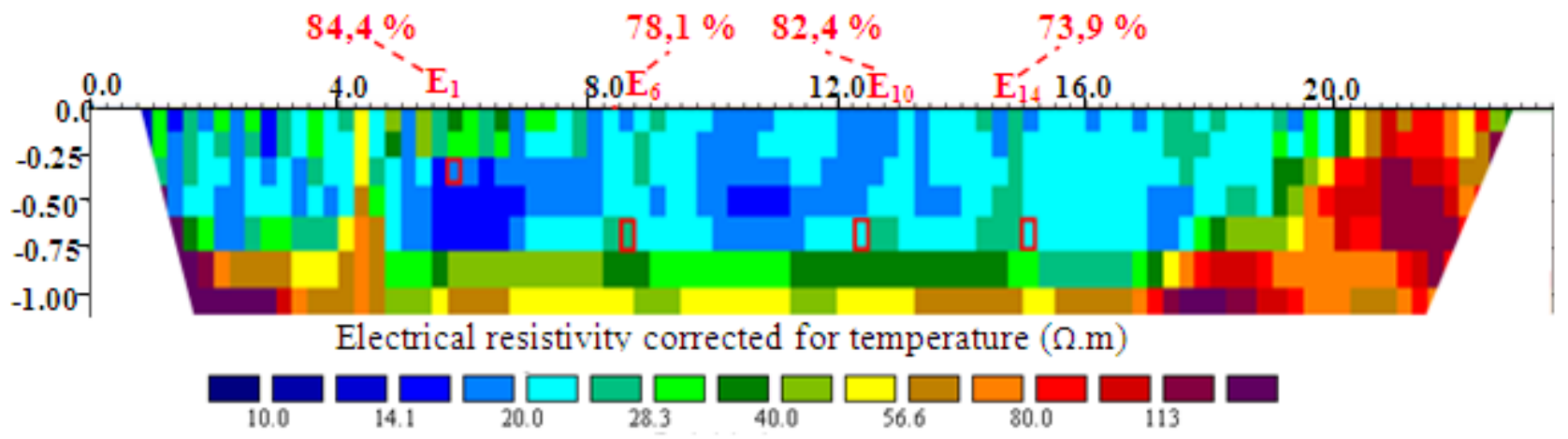

Figure 12 : Fines content of samples along $\mathrm{ERT}_{\mathrm{c}}$ profile 


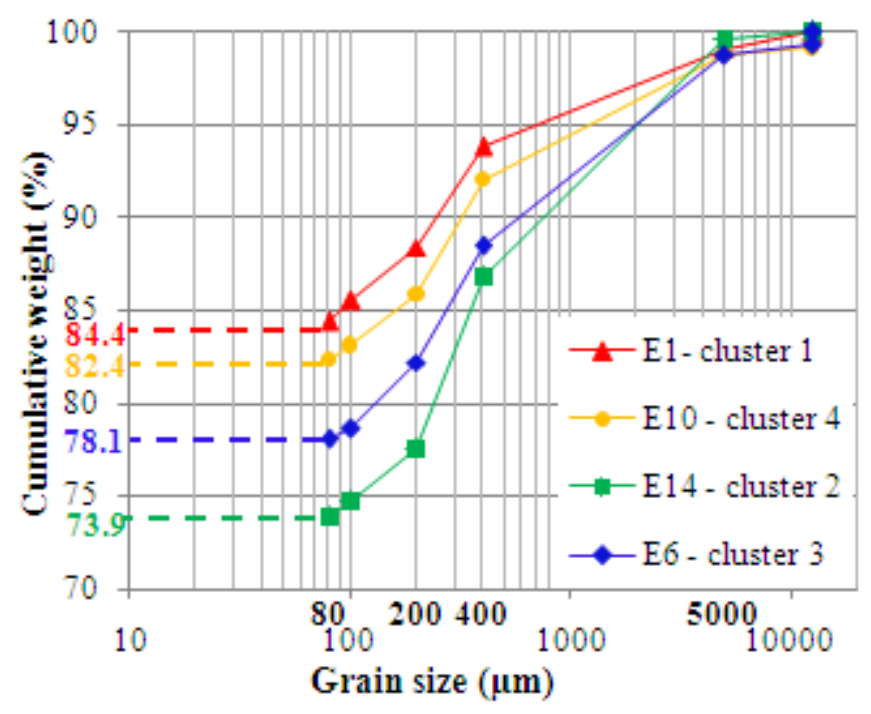

Figure 13: Particle-size distribution curve for the samples taken

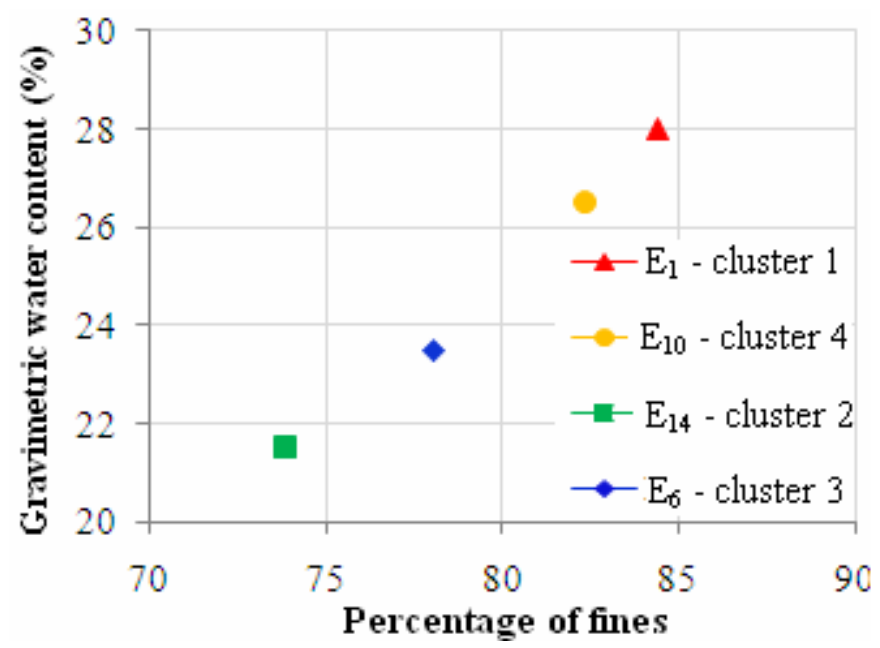

Figure 14: Percentage of fines as a function of the gravimetric water content for the four samples 


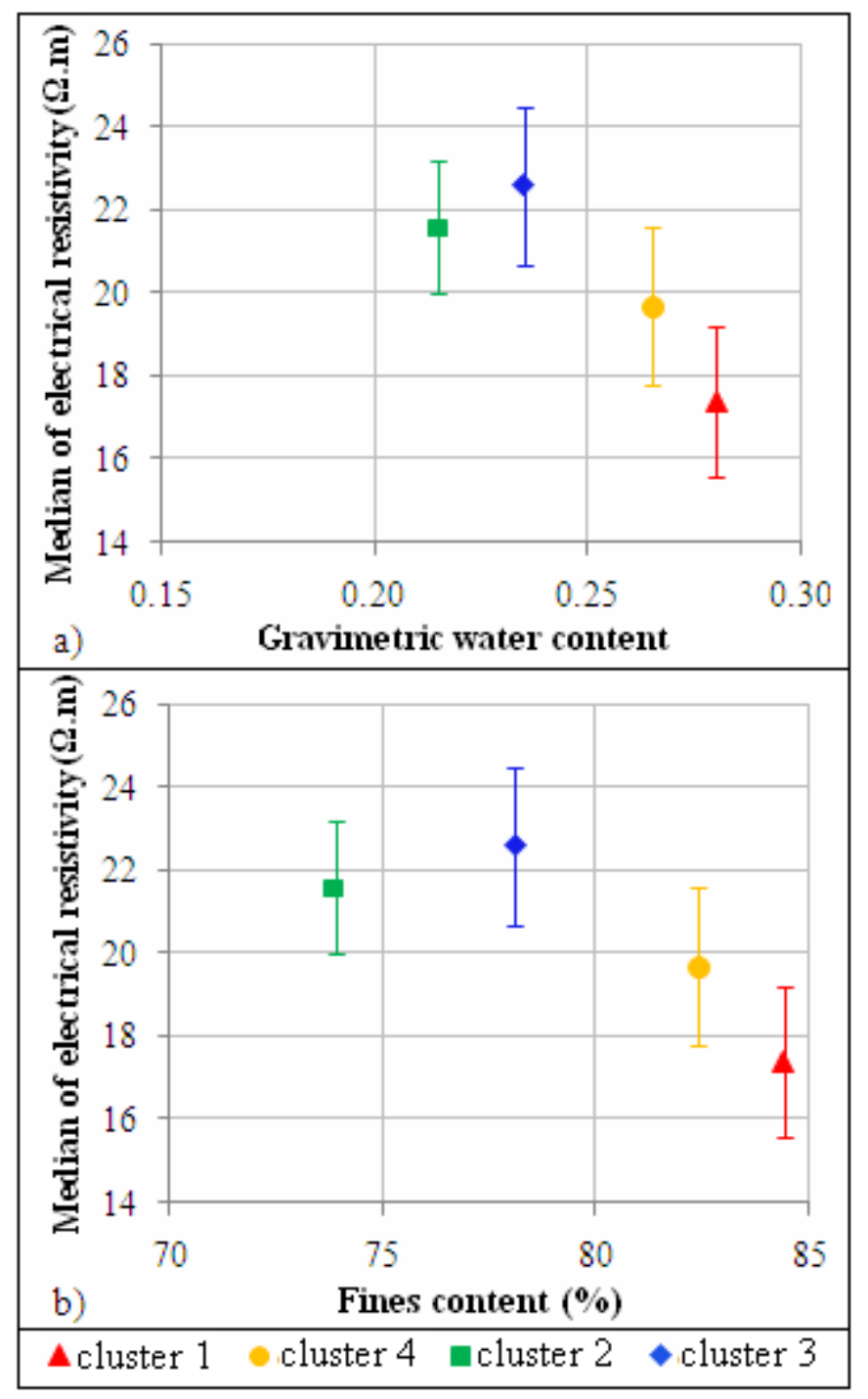

Figure 15: Median of electrical resistivity for the four clusters of ERT in relation to the gravimetric water content (a) and the fines content (b) of the four samples of loamyclay material 


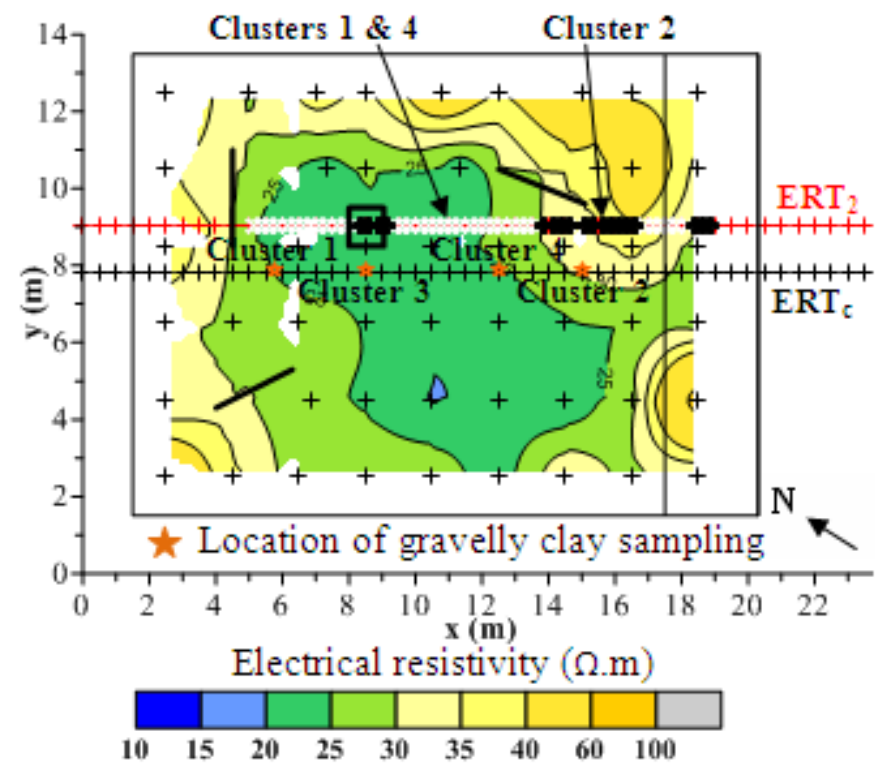

Figure 16: Map of resistivity corrected for temperature on the surface of layer 2 of the gravelly clay material (depth of $0.45 \mathrm{~m}$ )

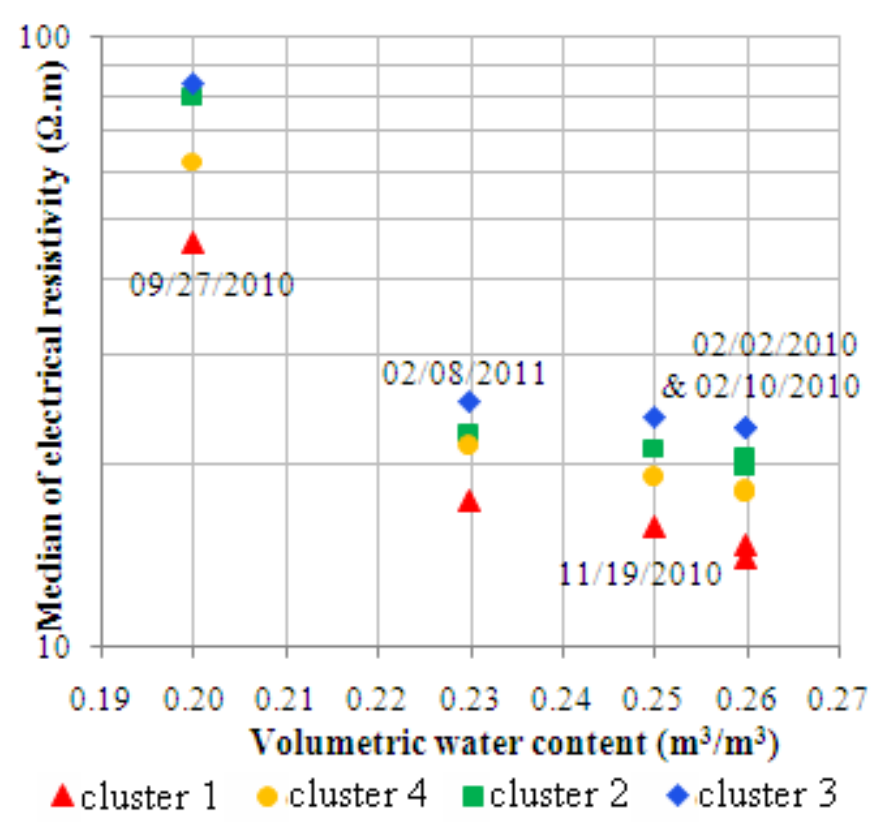

Figure 17: Median values of electrical resistivity of the four clusters of $\mathrm{ERT}_{2}$ as a function of the volumetric water content at a depth of $0.70 \mathrm{~m}$ during the five surveys 